\title{
PENGARUH MODAL INTELEKTUAL TERHADAP INVESTASI DAN KINERJA OPERASIONAL PERUSAHAAN PELAYARAN
}

\author{
Candra Oktyasari Putri ${ }^{1 *}$, Aditya Mutiara Dewi ${ }^{2}$ \\ ${ }^{1}$ Program Studi Tatalaksana Pelayaran Niaga dan Kepelabuhanan, Jurusan Bisnis Maritim, \\ Polimarin Semarang \\ ${ }^{2}$ Program Studi Transportasi Laut, Politeknik Bumi Akpelni Semarang \\ Jl. Pawiyatan Luhur I Bendan Duwur Gajahmungkur Semarang \\ *Email: candraoktyasariputri@ gmail.com
}

\begin{abstract}
Abstrak
Kinerja operasional perusahaan pelayaran nasional, khususnya yang terdaftar di Bursa Efek Indonesia (BEI), masih belum memuaskan. Hal ini antara lain ditandai oleh return on assets (ROA) sebagai indikator kinerja operasional perusahaan pelayaran yang terdaftar di BEI tahun 2016-2020 mengalami penurunan. Penurunan kinerja operasional pelayaran nasional tersebut memerlukan perbaikan melalui modal intelektual dan investasi. Modal intelektual sebagai aset tidak berwujud penting bagi perusahaan untuk meningkatkan keunggulan inti perusahaan yang dapat digunakan dalam meningkatkan kinerja operasional selain investasi dalam aset berwujud sehingga menarik untuk diteliti. Penelitian ini bertujuan untuk menganalisis pengaruh modal intelektual terhadap investasi dan kinerja operasional perusahaan pelayaran. Penelitian menggunakan metode kuantitatif. Sampelnya adalah 45 data tahunan 9 perusahaan pelayaran yang terdaftar di BEI pada poriode 2016-2020. Analisis data menggunakan statistik deskriptif dan statistik inferensial analisis jalur. Hasil penelitian menunjukkan bahwa modal intelektual tidak berpengaruh langsung terhadap investasi dan kinerja operasional, investasi berpengaruh langsung terhadap kinerja operasional, serta modal intelektual tidak berpengaruh langsung terhadap kinerja operasional dengan mediasi investasi. Dengan demikian peningkatan kinerja operasional perusahaan pelayaran dapat mempertimbangkan investasi dan dapat mengabaikan kondisi modal intelektual perusahaan. Temuan ini layak didiskusikan di kalangan peneliti dan praktisi, terutama untuk mengungkap kenapa modal intelektual tidak berpengaruh terhadap investasi dan kinerja operasional perusahaan.
\end{abstract}

Kata kunci: modal intelektual, investasi, kinerja operasional, pelayaran

\section{PENDAHULUAN}

Seiring berkembangnya zaman, transportasi di Indonesia semakin diperlukan semua kalangan. Keberadaan sarana transportasi dalam kehidupan manusia menjadi makin signifikan karena telah berkembang sebagai penunjang penting kelancaran berbagai aktivitas kehidupan. Transportasi telah menjadi bagian vital perkembangan manusia dan dunia, baik dalam hal pemerataan penduduk, pembangunan ekonomi dan pertumbuhan industrialisasi.

Dengan semakin pentingnya transportasi, maka jasa transportasi berkembang pesat untuk memenuhi kebutuhan manusia dan pembangunan suatu negara. Urgensi inilah yang menstimulasi tumbuhnya perusahaan transportasi termasuk perusahaan pelayaran dalam rangka menangkap peluang usaha di bidang jasa transportasi laut, yang kemudian mendorong terjadinya persaingan yang kompetitif antar perusahaan pelayaran. Persaingan tersebut dalam praktiknya memerlukan kinerja operasional perusahaan yang optimal.

Dalam realitasnya kinerja operasional perusahaan pelayaran nasional, khususnya yang terdaftar di Bursa Efek Indonesia (BEI), masih belum memuaskan. Hal ini antara lain ditandai oleh return on assets (ROA) sebagai indiaktor kinerja operasional perusahaan pelayaran yang terdaftar di BEI tahun 2016-2020 pada Tabel 1. 
Tabel 1. Kinerja Operasional 9 Perusahaan Pelayaran yang Terdaftar di BEI Tahun 2016-2020

\begin{tabular}{|l|l|l|l|l|l|}
\hline Ket & $\mathbf{2 0 1 6}$ & $\mathbf{2 0 1 7}$ & $\mathbf{2 0 1 8}$ & $\mathbf{2 0 1 9}$ & $\mathbf{2 0 2 0}$ \\
\hline $\begin{array}{c}\text { Rata- } \\
\text { rata } \\
\text { ROA }\end{array}$ & -3.49 & -1.38 & 2.07 & 1.36 & 0.09 \\
\hline
\end{tabular}

Sumber: BEI, 2021

Berdasarkan Tabel 1, kinerja operasional perusahaan pelayaran yang terdaftar di BEI berfluktuatif. Pada tahun 2018 mengalami kenaikan, kemudian pada dua tahun berikutnya mengalami menurun.

Kinerja operasional antara lain dapat dipengaruhi oleh modal intelektual (Kusumowati \& Meiranto, 2014). Modal intelektual menjadi salah satu faktor utama dalam iklim pasar yang mendorong pertumbuhan dan daya saing (Lamond, 2010). Sebagai aset tidak berwujud, modal intelektual mungkin sulit untuk menilainya. Untuk mengidentifikasi dan menjelaskan modal intelektual, perlu diperhatikan pengembangan nilai, keunggulan kompetitif dan kesuksesan organisasi (Obeidat, 2017).

Selain dipengaruhi oleh modal intelektual, kinerja operasional juga dapat dipengaruhi oleh investasi (Lee, Rho \& Yoon, 2015). Perusahaan pelayaran dicirikan oleh tingginya tingkat hutang dan aset berwujud. Perusahaan pelayaran membutuhkan investasi besar dan terus berinvestasi dalam fasilitas, kapal, dan lainlain (Yeo, 2018).

\section{LANDASAN TEORI \\ Perusahaan Pelayaran}

Perusahaan pelayaran menurut Suwarno (2011), adalah badan usaha milik negara atau swasta, berbentuk perusahaan negara persero, Perseroan Terbatas (PT), Perseroan Comanditer (CV), dan lain-lain yang melakukan usaha jasa dalam bidang penyediaan ruangan kapal laut untuk kepentingan mengangkut muatan penumpang (orang) dan barang (dagangan) dari suatu pelabuhan asal (muat) ke pelabuhan tujuan (bongkar), baik di dalam negeri (interinsulair) maupun luar negeri (ocean going shipping).

\section{Modal intelektual}

Modal intelektual penting bagi perusahaan dalam rangka meningkatkan keunggulan inti perusahaan yang dapat digunakan untuk meningkatkan kinerja perusahaan. Menurut Soetedjo dan Mursida (2014), modal intelektual adalah materi intelektual-pengetahuan, informasi, hak pemilikan intelektual, pengalaman yang dapat digunakan untuk menciptakan kekayaan. Sedangkan menurut Moeheriono (2012), modal intelektual merupakan pengetahuan (knowledge) dan kemampuan (ability) yang dimiliki oleh suatu kolektivitas sosial, seperti sebuah organisasi komunitas intelektual, atau praktik profesional serta modal intelektual mewakili sumber daya yang bernilai tinggi dan berkemampuan untuk bertindak yang didasarkan pada pengetahuan. Bagi Ivan dan Luky (2013), istilah modal intelektual memiliki arti lebih dari sekedar kecerdasan (intellect) yang dimiliki oleh perusahaan saja, tetapi merupakan sebuah proses ideologis untuk mencapai tujuan perusahaan. Dalam perkembangannya, modal intelektual didefinisikan sebagai sumber daya non-fisik atau sumber daya tidak berwujud yang dimanfaatkan perusahaan untuk meningkatkan nilai tambahnya.

Ulum (2013), berpendapat bahwa istilah modal intelektual diperlakukan sebagai sinonim dari intangible assets. Meskipun demikian, definisi yang diajukan OECD menyajikan cukup perbedaan dengan meletakkan modal intelektual sebagai bagian terpisah dari dasar penetapan intangible asset secara keseluruhan suatu perusahaan. Dengan demikian, terdapat item-item intangible asset yang secara logika tidak membentuk bagian dari modal intelektual suatu perusahaan. Salah satunya adalah reputasi perusahaan. Reputasi perusahaan mungkin merupakan hasil sampingan (atau suatu akibat) dari 
penggunaan modal intelektual secara bijak dalam perusahaan, tapi itu bukan merupakan bagian dari modal intelektual. Ikhsan (2012), mendefinisikan modal intelektual sebagai nilai total dari suatu perusahaan yang menggambarkan aktiva tidak berwujud (intangible asstes) perusahaan yang bersumber dari tiga pilar, yaitu modal manusia, struktural dan pelanggan.

\section{Investasi}

Perusahaan agar tetap tumbuh memerlukan investasi sehingga kinerja perusahaan dapat terus meningkat. Menurut Tandelilin (2017), investasi adalah komitmen atas sejumlah dana atau sumberdaya lainnya yang dilakukan pada saat ini dengan tujuan memperoleh sejumlah keuntungan di masa yang akan datang. Sedangkan menurut (Bodi et al, 2017), investasi adalah pengorbanan atas uang atau sumber daya lainnya dengan harapan memperoleh manfaat di masa yang akan datang. (Sukirno, 2016) mengartikan investasi sebagai pengeluaran penanaman modal atau perusahaan untuk membeli barang-barang modal dan perlengkapanperlengkapan produksi untuk menambah kemampuan memproduksi barang-barang dan jasa-jasa yang tersedia dalam perekonomian. Kemudian Jones (2014), mendefinisikan investasi sebagai pengorbanan atas dana untuk satu aset atau lebih yang dilakukan selama beberapa periode waktu di masa yang akan datang.

Investasi dalam arti luas terdiri dari dua bagian utama, yaitu: (1) investasi dalam bentuk aktiva rill (real asset) berupa aktiva berwujud seperti emas, perak, intan, barangbarang seni dan real estate; dan (2) investasi dalam bentuk surat-surat berharga (financial asset) berupa surat-surat berharga yang pada dasarnya merupakan klaim atas aktiva rill yang dikuasai oleh entitas. Pemilihan aktiva finansial dalam rangka investasi pada sebuah entitas dapat dilakukan dengan dua cara: (a) investasi langsung (direct investment), yakni suatu pemilikan surat-surat berharga secara langsung dalam suatu entitas yang secara resmi telah go publmodal intelektualdengan harapan akan mendapatkan keuntungan berupa penghasilam dividen dancapital gains; (b) investasi tidak langsung (indirect investment), yaitu terjadi bilamana suratsurat berharga yang dimiliki diperdagangkan kembali oleh perusahaan investasi (investment company) yang berfungsi sebagai perantara (Sunariyah, 2013).

\section{Kinerja Operasional}

Menurut Wirawan (2012), kinerja adalah keluaran yang dihasilkan oleh fungsifungsi atau indikator-indikator suatu pekerjaan atau suatu profesi dalam waktu tertentu. Simanjuntak (2012), menyatakan bahwa kinerja individu adalah tingkat pencapaian atau hasil kerja seseorang dari sasaran yang harus dmodal intelektualapai atau tugas yang harus dilaksanakan dalam kurun waktu tertentu, sedangkan kinerja perusahaan adalah tingkat pencapaian atau tujuan yang harus dmodal intelektualapai oleh perusahaan dalam kurun waktu tertentu. Menurut Armstrong (2012), kinerja merupakan luaran dari pencapaian tujuan secara kuantitatif. Armstrong dan Baron, dalam Wibowo (2014), menjelaskan bahwa kinerja merupakan hasil pekerjaan yang mempunyai hubungan kuat dengan tujuan strategis organisasi, kepuasan konsumen, dan memberikan konstribusi pada ekonomi.

Untuk mengetahui hasil kinerja diperlukan penilaian atau pengukuran. Menurut Dessler (2012), penilaian kinerja adalah evaluasi kinerja relatif karyawan saat ini dan atau yang telah berlalu terhadap standar kerjanya. Penilaian kinerja juga merupakan suatu proses menilai kinerja secara sistematis dan memberikan umpan balik atas penilaian kinerja yang telah dibuat (Schermerhorn, Hunt, \& Osborn, 2012). Hanafi (2014), menyatakan bahwa pengukuran kinerja merupakan kualifikasi dan efisiensi serta efektivitas perusahaan dalam pengoperasian bisnis selama periode akuntansi. Dengan demikian, kinerja merupakan suatu usaha formal yang dilaksanakan perusahaan untuk 
mengevaluasi efisien dan efektivitas dari aktivitas perusahaan yang telah dilaksanakan pada periode waktu tertentu.

Sementara itu, operasi adalah bagian dari organisasi bisnis yang bertugas untuk memproduksi barang atau jasa. Barang merupakan peralatan fisik yang mencakup bahan mentah, parts, subassemblies seperti motherboards yang merupakan bagian dari komputer, dan produk akhir seperi telephon genggam; sedangkan jasa adalah aktivitas yang memberikan kombinasi nilai dari waktu, lokasi dan nilai psikologis (Stevenson, 2014). Sejalan dengan pengertian kinerja dan operasi di atas, maka kinerja operasional didefinisikan sebagai efektivitas penggunaan sumber daya di dalam perusahaan seperti modal, bahan baku, teknologi, dan lain-lain (Moeheriono, 2012). Bagi Prastowo (2015), kinerja operasional yakni penilaian mengenai efisiensi operasi perusahaan.

\section{Modal Intelektual dan Kinerja Operasional}

Beberapa penelitian mengenai pengaruh modal intelektual terhadap kinerja telah dilakukan, antara lain: manajemen modal intelektual berpengaruh terhadap daya saing dan kinerja keuangan (Kianto, Andreeva, \& Pavlov, 2013). Penelitian Lee $\&$ Lin (2019), mengenai determinan kinerja operasional dalam perfektif modal intelektual menunjukkan bahwa kinerja operasi lebih baik untuk perusahaan dengan karyawan muda, mayoritas staf lapangan, biaya tenaga kerja yang tinggi, usia bisnis yang panjang, lebih banyak perusahaan konsultan manajemen, rasio biaya pemasaran yang tinggi, dan penyediaan layanan. modal intelektual juga berpengaruh terhadap kinerja keuangan (Olarewaju \& Msomi, 2021). Begitu pula proses manajemen pengetahuan berpengaruh terhadap kinerja organisasi (Sahibzada et al., 2020). Modal intelektual juga berpengaruh terhadap kinerja perusahaan (Kusumowati \& Meiranto, 2014). Secara empiris, value added intellectual capital (VA intellectual capital) untuk mengukur modal intelektual dan komponennya terbukti berpengaruh positif dan signifikan terhadap profitabilitas (Alipour, 2012). Hasil serupa didokumentasikan oleh Mehralian, et al. (2012) di sektor farmasi Iran selama periode 2004 hingga 2009. Dalam studinya, kinerja diukur menggunakan ROA dan produktivitas (rasio total pendapatan terhadap nilai buku perusahaan $=\mathrm{ATO}$ ). Dengan demikian dapat dihipotiskan:

$\mathrm{H}_{1}$ : Modal intelektual berpengaruh langsung terhadap kinerja operasional.

\section{Investasi dan Kinerja Operasional}

Penelitian Antonietti dan Marzucchi (2014), menunjukkan bahwa investasi pada aset ramah lingkungan berpengaruh terhadap kinerja. Setelah menerima investasi dari modal ventura, perusahaan rata-rata mencapai ROS dan ROE yang lebih tinggi dibandingkan dengan perusahaan yang tidak didukung modal ventura (Jiang \& Guo, 2013). Investasi juga berpengaruh terhadap kinerja organisasi (Lee, Rho \& Yoon, 2015). Selain itu, investasi efisiensi sumber daya berpengaruh terhadap kinerja perusahaan (Ozbugday, et. al., 2020). Dengan demikian dapat dihipotiskan:

$\mathrm{H}_{2}$ : Investasi berpengaruh langsung terhadap kinerja operasional.

\section{Modal intelektual dan Investasi}

Kebijakan investasi dilakukan untuk meningkatkan nilai perusahaan yang menekankan pada peluang investasi yang ditetapkan sebagai mediasi penting antara modal intelektual dan nilai perusahaan (Sumiati, et al., 2019). Ghadim (2020), menyatakan bahwa modal intelektual yang terdiri dari efisiensi modal manusia, modal struktural dan modal karyawan dapat dimanfaatkan sebagai sumber daya yang berharga untuk peluang investasi yang menguntungkan bagi perusahaan untuk diperhitungkan. Dengan demikian, keefektifan modal intelektual berpotensi menjadi tolok ukur untuk mengukur dan melaporkan kumpulan peluang investasi 
yang menguntungkan. Dengan demikian dapat dihipotiskan:

$\mathrm{H}_{3}$ : modal intelektual berpengaruh langsung terhadap investasi

\section{Modal intelektual dan Kinerja Operasional dengan Mediasi Investasi}

Uraian di atas menunjukkan bahwa modal intelektual dapat berpengaruh langsung terhadap investasi (Sumiati, et al., 2019; Ghadim, 2020) dan investasi berpengaruh langsung terhadap kinerja operasional (Antonietti dan Marzucchi, 2014; Jiang \& Guo, 2013; Lee, Rho \& Yoon, 2015; Ozbugday, et. al., 2020). Hal ini membuka peluang bagi terjadinya pengaruh tidak langsung modal intelektual terhadap kinerja operasional dengah mediasi investasi. Modal intelektual yang tinggi akan meningkatkan investasi yang pada akhirnya kinerja operasional dapat meningkat. Dengan demikian dapat dihipotiskan:

$\mathrm{H}_{4}$ : Modal intelektual berpengaruh tidak langsung terhadap kinerja operasional dengan mediasi investasi

\section{METODE}

Penelitian ini menggunakan metode kuantitatif. Sampelnya adalah perusahaan pelayaran yang terdaftar di BEI tahun 20162020, yakni 45 pengamatan dari 9 perusahaan selama 5 tahun. Modal intelektual dengan indikator tobin's q. Investasi menggunakan indikator pertumbuhan aset tetap. Kinerja operasional dengan indikator return on assets (ROA). Analisis statistik yang digunakan dalam penelitian ini adalah analisis jalur (Path Analysis) menggunakan SmartPLS. Pengggunaan Partial Least Square (PLS) dikarenakan dapat digunakan untuk menaksir analisis jalur, distribusi data tidak harus normal, dan sampel kecil. Kemudian untuk menguji signifikansi koefisien jalur digunakan uji $t$, dan nilai thitung yang diperoleh dibandingkan dengan nilai $t_{\text {tabel. }}$. Jika nilai $t_{\text {hitung }}>t_{\text {tabel }}$ signifikan, sebaliknya nilai $t_{\text {hitung }}<t_{\text {tabel }}$ tidak signifikan.

\section{HASIL DAN PEMBAHASAN}

Analisis statistik deskriptif dan korelasi ketiga variabel penelitian dengan sampel sembilan perusahaan pelayaran yang terdaftar di BEI tahun 2016-2020 disajikan pada Tabel 2 dan 3. Nilai rata-rata ketiga variabel dari yang terendah hingga tertinggi berturut-turut adalah kinerja operasional (0,268), investasi (0,053), dan modal intelektual (1,436). Rata-rata kinerja operasional -0,268 menunjukkan kinerja yang rendah, rata-rata investasi sebesar 0,053 menunjukkan investasi yang rendah, dan rata-rata modal intelektual sebesar 1,436 menunjukkan modal intelektual yang tinggi. Sedangkan nilai standar deviasi ketiga variabel dari yang terendah hingga tertinggi berturut-turut adalah kinerja operasional $(6,806)$, modal intelektual (1,340), dan investasi (0,309). Hasil analisis korelasi menunjukkan bahwa hanya variabel investasi dan kinerja operasional memiliki hubungan signifikan pada $\mathrm{p}<0,01$. Koefisien korelasi dari yang terendah hingga tertinggi berturut-turut adalah modal intelektual dan kinerja operasional $(0,098)$, investasi dan modal intelektual $(0,140)$, investasi dan kinerja operasional $(0,398)$.

\section{Tabel 2. Statistik Deskriptif}

\begin{tabular}{lcc}
\hline \multicolumn{1}{c}{ Variabel } & Rata-rata & Std. Deviasi \\
\hline 1. Modal intelektual & 1,436 & 1,340 \\
2. Investasi & 0,053 & 0,309 \\
3. Kinerja Operasional & $-0,268$ & 6,806 \\
\hline Sumber: Hasil Pengolahan Data & &
\end{tabular}

\section{Tabel 3. Matriks Korelasi}

\begin{tabular}{lccc}
\hline \multicolumn{1}{c}{ Variabel } & $\mathbf{1}$ & $\mathbf{2}$ & $\mathbf{3}$ \\
\hline 1. Modal intelektual & 1,00 & & \\
2. Investasi & 0,140 & 1,00 & \\
3. Kinerja Operasional & 0,098 & $0,397 * *$ & 1,00 \\
\hline ** $\mathrm{p}<.01$ & & \\
Sumber: Hasil Pengolahan Data & & &
\end{tabular}

Hasil pengujian hipotesis dengan analisis jalur pengaruh modal intelektual terhadap investasi dan kinerja operasional 
dirangkum dalam Tabel 3 dan divisualisasikan pada Gambar 1 dan Gambar 2.

Hasil pengujian hipotesis menunjukkan bahwa modal intelektual tidak berpengaruh langsung terhadap kinerja operasional dengan indikasi nilai koefisien jalur 0,042 dan nilai $t_{\text {hitung }}=0,235<t_{\text {tabel }}$ pada $\alpha=0,05(1,67)$; investasi berpengaruh langsung positif dan sangat signifikan terhadap kinerja operasional dengan indikasi nilai koefisien jalur 0,392 dan nilai $t_{\text {hitung }}=$ $3,748>t_{\text {tabel }}$ pada $\alpha=0,01(2,41)$; modal intelektual tidak berpengaruh langsung terhadap investasi, dengan indikasi nilai koefisien jalur 0,140 dan nilai $t_{\text {hitung }}=1,028$ $<t_{\text {tabel }}$ pada $\alpha=0,05(1,67)$; dan modal intelektual tidak berpengaruh tidak langsung terhadap kinerja operasional dengan mediasi investasi dengan indikasi nilai koefisien jalur 0,055 dan nilai $\mathrm{t}_{\text {hitung }}=0,924<\mathrm{t}_{\text {tabel }}$ pada $\alpha=0,05(1,67)$.

Tabel 4. Rangkuman Hasil Koefisien Jalur \& t-Hitung

\begin{tabular}{cccc}
\hline Jalur & $\begin{array}{c}\text { Koefisien } \\
\text { Jalur }\end{array}$ & $\begin{array}{c}\text { T } \\
\text { Hitung }\end{array}$ & Keterangan \\
\hline Modal & & &
\end{tabular}

Modal

Intelektual

terhadap

Kinerja

0,042

0,235

Operasional

Investasi

terhadap

Kinerja

Operasional

$0,392 \quad 3,748 * *$

Modal

Intelektual

terhadap $\quad 0,140 \quad 1,028$

Investasi

Modal

Intelektual

terhadap

0,055

Kinerja

Tidak

Signifikan
Operasional

dengan

Mediasi

Investasi

$* * \mathrm{p}<.01$

Sumber: Hasil Pengolahan Data

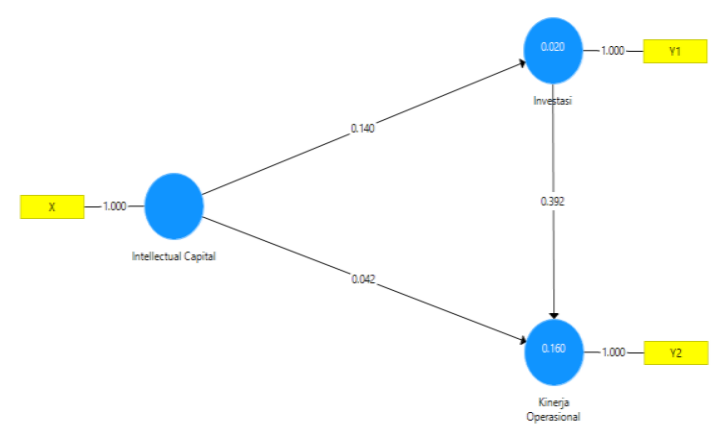

Gambar. 1 Koefisien jalur

Sumber: Hasil Pengolahan Data

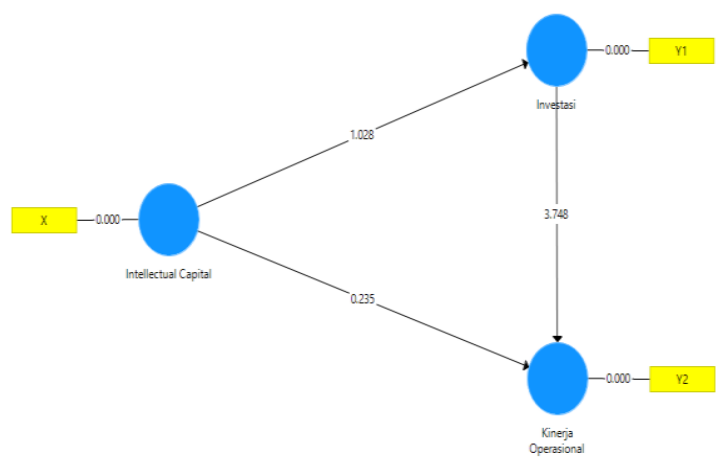

Gambar 2. t-hitung

Sumber: Hasil Pengolahan Data

Hasil penelitian ini secara empirik membuktikan bahwa modal intelektual tidak berpengaruh langsung terhadap kinerja operasional. Modal intelektual yang dimiliki perusahaan tidak dimanfaatkan secara efisien dan efektif dalam operasional perusahaan. Dengan kondisi demikian maka modal intelektual tidak berpengaruh

Tidak langsung terhadap kinerja operasional. Hasil Signifikan penelitian ini tidak sejalan beberapa penelitian yang menunjukkan bahwa modal intelektual berpengaruh terhadap kinerja operasional (Alipour, 2012; Mehralian et

Tidak al., 2012; Venugopal \& Madukkarai, 2012; Signifikan Kianto, Andreeva \& Pavlov, 2013; Shih dan Tsai, 2014; Kusumowati \& Meiranto, 2014; Lee \& Lin, 2019; Sahibzada et. al., 2020; 
Olarewaju \& Msomi, 2021). Dengan demikian temuan penelitian ini tidak mendukung hasil penelitian sebelumnya bahwa modal intelektual berpengaruh langsung terhadap kinerja operasional dengan setting penelitian pada perusahaan pelayaran yang terdaftar di BEI.

Hasil penelitian ini secara empirik juga membuktikan bahwa investasi berpengaruh langsung positif dan sangat signifikan terhadap kinerja operasional. Hal ini berarti bahwa investasi dapat meningkatkan kinerja operasional. Investasi yang dilakukan oleh perusahaan pada aset tetap dapat meningkatkan efisiensi operasional perusahaan dalam memperoleh keuntungan bagi perusahaan. Kondisi ini akan meningkatkan kinerja operasional. Hasil penelitian ini sejalan beberapa peneliti yang membuktikan bahwa investasi berpengaruh terhadap kinerja perusahaan (Jiang \& Guo, 2013; Antonietti \& Marzucchi, 2014; Lee, Rho \& Yoon, 2015; Ozbugday et al., 2020). Dengan demikian temuan penelitian mendukung hasil penelitian sebelumnya bahwa investasi berpengaruh langsung terhadap kinerja operasional dengan setting penelitian pada perusahaan pelayaran yang terdaftar di BEI.

Hasil penelitian ini secara empirik juga membuktikan bahwa modal intelektual tidak berpengaruh langsung terhadap investasi. Modal intelektual yang dimiliki oleh perusahaan tidak dimanfaatkan dengan baik sebagai sumber daya untuk mengeksplorasi peluang-peluang investasi yang ada sehingga investasi dapat diwujudkan untuk memperoleh keuntungan bagi perusahaan. Hasil penelitian ini tidak sejalan beberapa penelitian yang menunjukkan bahwa modal intelektual berpengaruh terhadap investasi (Czarnitzki \& Thorwarth, 2012; Gao et al., 2013; Jafaridehkordi \& Rahim, 2014; Sumiati et al., 2019; Ghadim, 2020). Dengan demikian temuan penelitian ini tidak mendukung hasil penelitian sebelumnya bahwa modal intelektual berpengaruh langsung terhadap investasi dengan setting penelitian pada perusahaan pelayaran yang terdaftar di BEI.

Hasil penelitian ini secara empirik juga membuktikan modal intelektual tidak berpengaruh tidak langsung terhadap kinerja operasional dengan mediasi investasi. Hasil penelitian menunjukkan bahwa modal intelektual tidak berpengaruh terhadap investasi dan investasi berpengaruh terhadap kinerja operasional. Hal ini tidak membuka peluang bagi pengaruh modal intelektual tidak berpengaruh tidak langsung terhadap kinerja operasional melalui investasi. Dengan demikian temuan penelitian ini tidak mendukung hasil penelitian sebelumnya bahwa modal intelektual berpengaruh langsung terhadap investasi dan investasi berpengaruh langsung terhadap kinerja operasional dengan setting penelitian pada perusahaan pelayaran yang terdaftar di BEI.

\section{KESIMPULAN}

Modal intelektual tidak berpengaruh langsung terhadap investasi dan kinerja operasional, investasi berpengaruh langsung terhadap kinerja operasional, serta modal intelektual tidak berpengaruh langsung terhadap kinerja operasional dengan mediasi investasi. Dengan demikian, peningkatan kinerja operasional perusahaan pelayaran dapat mempertimbangkan investasi dan dapat mengabaikan kondisi modal intelektual perusahaan. Temuan ini layak didiskusikan di kalangan peneliti dan praktisi, terutama untuk mengungkap kenapa modal intelektual tidak berpengaruh terhadap investasi dan kinerja operasional perusahaan.

\section{DAFTAR PUSTAKA}

Alipour, M., 2012, The effect of intellectual capital on firm performance: an investigation of Iran insurance companies, Measuring Business Excellence, Vol. 16, No. 1, pp. 5366.

Antonietti, R., \& Marzucchi, A., 2014, Green tangible investment strategies and export performance: A fi rm- 
level investigation, Ecological Economics, 108, 150-161.

Armstrong, G. 2012, Prinsip-prinsip pemasaran, Jilid 1 dan 2, Edisi Kedua Belas, Erlangga, Jakarta.

Bodi, Z., Kane, A., \& Marcus, A. J., 2017, Investment and portfolio management, McGraw-Hill, New York.

Czarnitzki, D., \& Thorwarth, S., 2012, The contribution of in-house and external design activities to product market performance, Journal of Product Innovation Management, Vol. 29, No5, pp. 878-895.

Dessler, G., 2012, Fundamental of human resources management: content, competencies and applications, Pearson Education, Inc, New Jersey.

Ghadim, R. B., 2020, The survey of relationship between efficiency of capital intellectual and investment opportunity set of companies listed in tehran stock exchange. Applied mathematics in Engineering, Management and Technology. https://ssrn.com/abstract=3606503.

Gao, H., Harford, J., \& Li, K. J. J.O.F.E., 2013, Determinants of corporate cash policy: Insights from private firms, Journal of Financial Economics forthcoming, 109, 623639.

Hanafi, M., 2014, Manajemen keuangan. BPFE, Yogyakarta.

Ikhsan, A., 2012, Akuntansi sumber daya manusia, Graha Ilmu, Yogyakarta.

Ivan, G. H., \& Luky, P., 2013, Pengaruh intellectual capital terhadap profitabilitas, produktivitas, dan penilaian pasar perusahaan sektor perbankan, Jurnal Gema Aktualita, Vol. 2, No.2, pp. 29-40.

Jafaridehkordi, H., \& Rahim, R., 2014, intellectual capital and investment opportunity set, European Online Journal of Natural and Social Sciences, 3, 1030-1041.
Jiang, K., \& Guo, D., 2013, Venture capital investment and the performance of entrepreneurial firms: Evidence from China, Journal of Corporate Finance, 22, $375-$ 395. https://doi.org/10.1016/j.jcorpfi n.2013.07.001

Jones, C. P., 2014, Investment principles and concepts, John Wiley and Sons Singapore Pte. Ltd, Singapura.

Kianto, A., Andreeva, T., \& Pavlov, Y., 2013, The impact of intellectual capital management on company competitiveness and financial performance. Knowledge Management Research \& Practice, 11(2), $112-$ 122. doi: $10.1057 / \mathrm{kmrp} .2013 .9$

Kusumowati, M., \& Meiranto, W., 2014, Pengaruh intellectual capital terhadap kinerja perusahaan (Studi kasus pada perusahaan manufaktur yang terdaftar di Bursa Efek Indonesia. Diponegoro Journal of Accounting, Vol. 3, No. 19, pp. 111.

Lamond, D., Huang, Y.C., Wu, Y.C.J., 2010, Intellectual capital and knowledge productivity: the Taiwan biotech industry, Manag. Decis, Vol. 48, No 4, pp. 580-599.

Lee, C., \& Lin, C., 2019, The major determinants of in $f l$ uencing the operating performance from the perspective of modal intelektual: Evidence on CPA industry, Asia Pacific Management Review, 24, 124-139. https://doi.org/10.1016/j.apmrv.201 8.01 .006

Lee, D., Rho, B., \& Yoon, S.N., 2015, Effect of investments in manufacturing practices on process efficiency and organizational performance. Int. J. Production Economics, 162, 45-54. https://doi.org/10.1016/j.ijpe.2015.0 1.001

Mehralian, G., Rajabzadeh, A., Sadeh, M. R., \& Rasekh, H. R., 2012, 
intellectual capital and corporate performance in Iranian pharmaceutical industry, Journal of intellectual capital, Vol. 13, No.1, pp. 138-158.

Moeheriono, 2012, Pengukuran Kinerja Berbasis Kompetensi, Raja Grafindo Persada, Jakarta.

Mosavi, S. A., Nekoueizadeh, S., \& Ghaedi, M., 2012, A study of relations between intellectual capital components, market value and finance performance, African Journal of Business Management, Vol. 6, No.4, pp. 1396-1403.

Obeidat, et al. 2017, The Effect of Intellectual Capital on Organizational Performance : The mediating Role Of Knowledge Sharing, Communication and network, 9, 1-27

Olarewaju, O. M., \& Msomi, T. S., 2021, intellectual capital and financial performance of South African development community's general insurance companies, Heliyon, 87(4).

Özbuğday, F. C., Findik, D., Özcan, K. M., \& Başçi, S., 2019, Resource Efficiency Investments and Firm Performance: Evidence from European SMEs. Journal of Cleaner Production,

119824. doi:10.1016/j.jclepro.2019. 119824

Prastowo, D., 2015, Analisis Laporan Keuangan: Konsep dan Aplikasi, UPP STIM YKPN, Yogyakarta:

Sahibzada, U. F., Jianfeng, C., Latif, K. F., Shafait, Z., \& Sahibzada, H. F., 2020, Interpreting the impact of knowledge management processes on organizational performance in Chinese higher education: mediating role of knowledge worker productivity, Studies in Higher Education, 1 18. doi:10.1080/03075079.2020.179 3930
Schermerhorn, John R., Jr, James G. Hunt \& Richard N. Osborn, 2010, Organizational Behavior, John Wiley \& Sons, Inc., New Jersey.

Simanjuntak, P. J., 2012, Manajemen Evaluasi Kinerja, Edisi 3, Fakutas UI, Jakarta.

Shih, T. C., \& Tsai, S. F., 2014, An empirical study of the impact of intellectual capital on operating efficiency of group practice accounting firms in Taiwan. $\mathrm{Fu}$ Jen Management Review, Vol. 21, No. 2, pp. 55-84

Soetedjo, S., \& Mursida, S., 2014,. Pengaruh intellectual capital terhadap kinerja keuangan pada perusahaan perbankan, Jurnal SNA 17, 24-27.

Stevenson, W., J., 2014, Manajemen operasi perspektif asia, Salemba Empat, Jakarta.

Sukirno, S., 2016, Makro ekonomi: teori pengantar, Rajagrafindo Persada, Jakarta.

Sumiati, R. W., \& Iswari, H. R., 2019, intellectual capital exploitation in investment opportunity set through risk premium: strategy to increase company value, Advances in Economics, Business and Management Research, Vol.135, 284-294.

Sunariyah, 2013, Pengantar Pengetahuan Pasar Modal, Edisi Keenam, UPP STIM YKPN, Yogyakarta.

Suwarno, 2011, Manajemen Pemasaran Jasa Perusahaan Pelayaran, BP UNDIP, Semarang.

Tandelilin, E., 2017, Portofolio dan investasi: teori dan aplikasi, Edisi Pertama, Kanisius, Yogyakarta:

Ulum, I., 2013), Model pengukuran kinerja intellectual capital dengan IB-VAIC Di Perbankan Syariah, Inferensi, Vol. 7, No. 1, pp. 185-206.

Venugopal, D., \& Madukkarai, S. N. T. G., 2012, intellectual capital and value creation efficiency- an empirical investigation into the intellectual 
capital and financial performance of Indian Software Industry, Vol. 33, No. 1, pp. 119-132.

Wibowo, 2014, Manajemen kinerja, Rajawali Pers, Jakarta.

Wirawan, 2012, Evaluasi kinerja sumber daya manusia, Salemba Empat, Jakarta.

Yeo, H. J. 2018, Role of free cash flows in making investment and dividend decisions: The case of the shipping industry, Asian Journal of Shipping and Logistics, Vol. 34, No. 2, pp. 113-118. 